\title{
Fibrous Tissue
}

National Cancer Institute

\section{Source}

National Cancer Institute. Fibrous Tissue. NCI Thesaurus. Code C129504.

A tissue composed of bundles of collag enous white fibers between which are rows of connective tissue cells. 